Under the Mountain: Basic Training, Individuality, \& Comradeship

\title{
Samuel Clark
}

Department of Politics, Philosophy, \& Religion

County South

Lancaster University

Lancaster

LA1 4YL

sam.clark@lancs.ac.uk

Tel: 01524592449

Fax (departmental): 01524594238

Abstract:

This paper addresses questions of friendship and political community by investigating a particular complex case, comradeship in the life of the soldier. Close attention to soldiers' accounts of their own lives, successes and failures shows that the relationship of friendship to comradeship, and of both to the success of the soldier's individual and communal life, is complex and tense. I focus on autobiographical accounts of basic training in order to describe, and to explore the tensions between, two positions: (1) Becoming a soldier is a corrupting loss of individuality and moral sensitivity, and friendship is resistance to it. (2) Becoming a soldier is one form of flourishing, and comradeship - the soldier's distinctive form of friendship-is one of its constitutive virtues. I draw particularly on George Orwell's account of basic training and fighting in the Spanish Civil War, and on Tim O'Brien's account of basic training and fighting in Vietnam.

Keywords: individuality, friendship, comradeship, soldiers, basic training, George Orwell, Tim O’Brien. 


\section{One}

This paper explores questions of friendship and political community by investigating a particular complex case, comradeship in the life of the soldier, via two examples (I consider how far we can generalise from those examples in Section Five). I begin, then, with two fragments from twentieth-century war memoirs. First, Tim O'Brien's If I Die in a Combat Zone (O’Brien 2003): O’Brien is an American writer, best known for The Things They Carried (O’Brien 1990). He was born 1946, grew up in Minnesota, and was drafted in 1968; he was an infantryman in Vietnam from 1969 to 1970. If I Die in a Combat Zone is his memoir of that time, and a brilliant piece of practical philosophy about courage, violence, and friendship. I shall focus on his chapter 5, 'Under the Mountain', from which I take my title, and which is about O'Brien's experience of basic training at Fort Lewis, Washington: the mountain is Mt. Rainer, and 'it stood for freedom' (O'Brien 2003, p. 40). O’Brien hated basic, and hated the army, as an attack on his individuality, conscience, and intelligence. The one thing which made it barely tolerable was his friend Erik:

Erik talked about poetry and philosophy and travel. But he talked about soldiering, too. We formed a coalition. It was mostly a coalition against the army, but we aimed also at the other trainees. The idea, loosely, was to preserve ourselves. It was a two-man war of survival, and we fought like guerillas, jabbing in the lance, drawing a trickle of army blood, running like rabbits. We hid in the masses. Right under their bloodshot eyes. We exposed them, even if they were blind and deaf to it. It was a war of resistance; the objective was to save our souls. Sometimes it meant hiding the remnants of conscience and consciousness behind battle cries, pretended servility, bare, clench-fisted obedience. Our private conversations were the cornerstone of the resistance, perhaps because talking about basic training in careful, honest words was by itself an insult to army education. Simply to think and talk and try to understand was evidence that we were not cattle or machines. (O’Brien 2003, pp. 42-43)

That is: for O'Brien, friendship was resistance to the soldier's corrupting life, and in particular, resistance to comradeship_to joining in with his fellow trainees-as one of the evils which make up that corrupting life.

I shall come back to O'Brien; for now, I want to make a contrast with another fragment, this one from George Orwell's Homage to Catalonia (Orwell 2001). In 1936, Orwell went to Spain with the International Brigades to fight against Franco's fascist 
coup. In the first part of the Spanish civil war, resistance to the fascists was organised not by the Republican government, but by the anarchist and socialist trade-unions (POUM, CNT, UGT) who put their democratic, socialist, and anti-clerical principles into practice, in farms, factories, and the militias (Alexander 1999; Preston 1996). Orwell's basic training was very different from O’Brien's:

Later it became the fashion to decry the militias, and therefore to pretend that the faults which were due to lack of training and weapons were the result of the equalitarian system. Actually, a newly raised draft of militia was an undisciplined mob not because the officers called the privates 'Comrade' but because raw troops are always an undisciplined mob. In practice the democratic 'revolutionary' type of discipline is more reliable than might be expected. In a workers' army discipline is theoretically voluntary. It is based on class loyalty, whereas the discipline of a bourgeois conscript army is based ultimately on fear ... In the militias the bullying and abuse that go on in an ordinary army would never have been tolerated for a moment. The normal military punishments existed, but they were only invoked for very serious offences. When a man refused to obey an order you did not immediately get him punished; you first appealed to him in the name of comradeship. Cynical people with no experience of handling men will say instantly that this would never 'work', but as a matter of fact it does 'work' in the long run. The discipline of even the worst drafts of militia visibly improved as time went on. In January the job of keeping a dozen raw recruits up to the mark almost turned my hair grey. In May for a short while I was acting-lieutenant in command of about thirty men, English and Spanish. We had all been under fire for months, and I never had the slightest difficulty in getting an order obeyed or in getting men to volunteer for a dangerous job. 'Revolutionary' discipline depends on political consciousness - on an understanding of why orders must be obeyed; it takes time to diffuse this, but it also takes time to drill a man into an automaton on the barrack-square. (Orwell 2001, p. 50-51)

Later in Homage to Catalonia, Orwell looks back on his time in training and in the trenches:

However much one cursed at the time, one realized afterwards that one had been in contact with something strange and valuable. One had been in a community where hope was more normal than apathy or cynicism, where the word 'comrade' 
stood for comradeship and not, as in most countries, for humbug. One had breathed the air of equality. I am well aware that it is now the fashion to deny that Socialism has anything to do with equality. In every country in the world a huge tribe of party-hacks and sleek little professors are busy 'proving' that Socialism means no more than a planned state-capitalism with the grab-motive left intact. But fortunately there also exists a vision of Socialism quite different from this. The thing that attracts ordinary men to Socialism and makes them willing to risk their skins for it, the 'mystique' of Socialism, is the idea of equality; to the vast majority of people Socialism means a classless society, or it means nothing at all. And it was here that those few months in the militia were valuable to me. For the Spanish militias, while they lasted, were a sort of microcosm of a classless society. In that community where no one was on the make, where there was a shortage of everything but no privilege and no boot-licking, one got, perhaps, a crude foretaste of what the opening stages of Socialism might be like. (Orwell 2001: 91)

That is: for Orwell, comradeship-equality, fraternity, and mutual loyalty shaped by revolutionary discipline - was the distinctive good of his time as a soldier. And more, it was a window into a possible future life in which humans flourish: a glimpse of utopia.

\section{Two}

These two fragments of autobiography dramatize a cluster of problems about the role or roles of friendship in the soldier's life, in politics, and in human life. How are friendship and comradeship related? Is one a subtype of the other, or are they in tension? Are they goods or evils in the soldier's life? By extension, are they goods or evils in buman life? Or, more accurately, in which human contexts and for what goals are they goods or evils?

My method for addressing these questions, and in other work on human flourishing, is autobiography as ethics (Clark 2010a, 2010b, and forthcoming, on all of which the rest of this section draws). I read autobiographies not just as examples for ethical thought—as if they were particularly elaborate thought-experiments-but as a distinctive and valuable kind of ethical thought. Autobiographical ethical thought involves, first, stepping back from the immediate and quotidian, and taking up a separated point of view on my own life-a diary kept at the time is not an autobiography, which requires that I as autobiographer take on 'a double character' as both investigator and object of investigation (Pascal 1960, p. 71). Second, considering how I have come over time to 
have my attitudes, projects, and pleasures. Third, judging my life as a whole: to what extent and in what parts was it successful, and to what extent and in what parts a failure?

For example, one of the central problems of If I Die in a Combat Zone is why O'Brien went to Vietnam: he could have dodged the draft by going to Canada, and he made detailed plans to desert to Sweden, but he found himself unable to go through with them. Part of the explanation of that incapacity is his childhood:

In patches of weed and clouds of imagination, I learned to play army games. Friends introduced me to the Army Surplus Store off main street. We bought dented relics of our fathers' history, rusted canteens and olive-scented, scarred helmet liners. Then we were our fathers, taking on the Japs and Krauts along the shores of Lake Okabena, on the flat fairways of the golf course, writhing insensible under barrages of shore batteries positioned under camouflage across the lake. I rubbed my fingers across my father's war decorations, stole a tiny battle star off one of them and carried it in my pocket. (O'Brien 2003, pp. 21-22) The adult O'Brien here takes up a third-person stance on his child self, and tries to uncover the roots of his compulsion to risk his life, and to kill, in a war which he thought unnecessary and unjust. The problem returns in discussions of cowardice and courage throughout the book.

This focus on the self-conscious investigation of individual development makes autobiography especially relevant to perfectionist ethics. Formally, perfectionism is a theory about the nature and significance of the Good. The perfectionist's claim about the nature of the Good is that it is flourishing, understood as the full development and successful performance of certain ways of functioning and being which are of central importance to human life. An individual human being's life goes best when she exemplifies and expresses human and individual potential to the full: for example, when she is healthy, creative, and independent (if those are the central human ways of functioning and being). Just as we might say that the successful life for an oak is to grow from acorn to spreading, ancient tree, rather than, for example, being shaped into a stunted bonsai; so, the perfectionist says that the successful life for a human is to grow into a flourishing adult, rather than, for example, being tyrannized into a tamed slave. The relevant contrast here is with theories which make other claims about the nature of the Good: a hedonist, for example, identifies the Good with pleasure and the absence of pain.

The perfectionist's claim about the significance of the Good is that it is the primary and independently-defined ethical concept. The content of the other basic ethical 
concept, the Right, is to be derived from it: the Right thing to do is to promote the Good. The relevant contrast in this case is that the perfectionist, like the utilitarian, is a teleologist rather than a deontologist (Rawls 1999): the teleologist claims that there are no independently or absolutely right or wrong actions, policies, institutions, or attitudes: everything right or wrong is so because of its consequences, as measured against the Good. Both the oak and the human, as living things in an unchosen and recalcitrant world, need certain favourable conditions if their flourishing is to be possible. Conditions are to be judged as right or wrong because good or bad for oaks or humans or any other living thing (see Foot 2001 for analysis of 'good for'). The conditions of buman flourishing in particular are significantly although not wholly created by human action and institutions, and facts about the successful life for humans are what justify or condemn such action and institutions.

Two obvious questions follow for the perfectionist: first, which ways of functioning and being are the ones central to human life, the development and successful performance of which constitute flourishing? What does a flourishing human adult possess and do? Second, how are we to promote human flourishing? What are its conditions? What nourishment and cultivation do we need to grow successfully, and to avoid enslavement and the other corruptions of human life?

My focus in this paper is the set of questions about friendship and comradeship raised by the fragments of military memoir with which I began, as a way into consideration of political friendship more generally. More precisely, I focus on basic training as an important crux or crisis in the life of the soldier: basic is deliberately and explicitly a point of major change-of breaking down and rebuilding — in a soldier's development, and soldiers' own understanding of basic as a developmental crisis is therefore particularly revealing about their flourishing, and by extension about buman flourishing. Or so I hope to show in what follows.

\section{Three}

With these methodological and definitional points in mind, I return to my two fragments. First, what follows from O'Brien's account of basic in If I Die in a Combat Zone? For O'Brien, comradeship is one of the evils of his experience of soldiering: one of the ways in which to become a soldier is to corrupt one's humanity, to maldevelop in a direction away from flourishing. It's closely connected with other corruptions actively pursued in basic. Destruction of individuality and privacy. Shaping by others rather than 
self-development. Erosion of moral identity (Glover 2001: 26-30). Replacement of thoughtful self-command with habit:

We march to the Quick-Kill rifle range. We learn to snap off our shots, quickly, rapidly, without conscious aim. Without any thought at all. Quick Kill. (O’Brien 2003, p. 50)

Normalization of both doing and being subject to violence. Deadening of moral inhibition, sympathy, and pity. Demotion of others to categories not worthy of respect: the civilian and the enemy. Promotion of an exclusive esprit de corps: we are a special breed, they are beneath contempt.

How is friendship opposed to comradeship and to these other, related evils? Both can involve affection and even love. But friendship is intimate rather than public: it's important for O'Brien and Erik that their conversations are hidden, and their sergeant takes vast and homophobic offence at their hiding away and talking only to each other. It is one-to-one rather than one-to-many or even many-to-many. And it is chosen rather than thrown together: comrades are more like fellow citizens or family-members than like friends; we don't get to pick them for ourselves, we just find ourselves in barracks with a platoon.

This is a preliminary, and probably incomplete, account of the distinctions between the concepts of friendship and comradeship; but it doesn't get us very far in answering the question, How does friendship work as resistance to comradeship and other evils of soldiering? I shall move towards an answer to that question by placing O’Brien and Erik's friendship in a taxonomy of forms of resistance which applies across several contexts of domination, for instance when slaves resist masters, or when peasants resist nation-states, as well as when conscripts resist armies. My point here is not to claim that friendship is always resistance, but to consider how the actions, dispositions, and situations which make up a friendship can be used against oppression.

As a first cut, we can distinguish resistance into individual and communal types: revolution and insurrection are the exemplary acts of communal resistance, as when slaves under Toussaint L'Ouverture revolted in Haiti in the late eighteenth century (James 1980). Friendship, in contrast, is individual resistance: it doesn't recruit or organize masses; as already noted, it is intimate and one-to-one.

Individual resistance can be further distinguished into open and bidden forms: those which are and intend to be visible to oppressors, and those which are, or at least 
intend to be, invisible. The open forms of resistance include, for example, pacifism. Consider e. e. cummings's Olaf:

i sing of Olaf glad and big

whose warmest heart recoiled at war:

a conscientious object-or

his wellbelovéd colonel(trig

westpointer most succinctly bred)

took erring Olaf soon in hand;

but—-though an host of overjoyed

noncoms(first knocking on the head

him)do through icy waters roll

that helplessness which others stroke

with brushes recently employed

anent this muddy toiletbowl,

while kindred intellects evoke

allegiance per blunt instruments-

Olaf(being to all intents

a corpse and wanting any rag

upon what God unto him gave)

responds, without getting annoyed

"I will not kiss your fucking flag"

(cummings 1969)

And, for an interestingly parallel example, consider warriors as distinguished from soldiers (Bourke 1999, chapter 2): warriors in this sense are combatants who manage to express their individuality by fighting in some sense alone, and who meet the enemy as a respected fellow warrior-a mirror image rather than a passive body on which weapons work. In twentieth century warfare, warriors have tended to be snipers and fighter pilots; or, more cautiously, they are the fighters who have most often been mythologized as honourable individualists. For one example, think of Siegfried Sassoon as described by his friend Robert Graves: awe-inspiringly fearless in combat and loved by the men under his command, but distrusted by his superiors, who-rightly—regarded him as a liability who couldn't be trusted to follow orders or to pursue their strategic objectives (Graves 1960). Or for another, think of Yeats's Irish airman: 
Nor law, nor duty bade me fight,

Nor public men, nor cheering crowds,

A lonely impulse of delight

Drove to this tumult in the clouds.

(Yeats 1989)

In contrast to both pacifists and warriors, friendship's use is as hidden resistance: O’Brien makes the analogy with guerilla warfare, but actually his and Erik's main act of resistance is talking privately; is, precisely, keeping something to themselves which is not public.

This hidden form of individual resistance is one example of what James Scott has called the 'weapons of the weak' (Scott 1985): forms of 'Brechtian—or Schweikian' resistance including 'foot-dragging, dissimulation, desertion, false compliance, pilfering, feigned ignorance, slander' (Scott 1985, p. xvi); mockery, satire, dumb insolence, deliberate incompetence-weapons which are familiar both in the antistatist peasant context Scott studies, and in day-to-day resistance by slaves (Craton 1982). O’Brien and Erik's friendship is one of the several weapons of the weak which they use. Another such weapon is that O'Brien learned to mimic shouting in chorus without actually making a sound:

I mouthed the words, shaping my lips and tongue just so, perfect deception. But no noise came out. The failure to bellow 'Yes, Drill Sergeant' was a fist in the bastard's face. (O’Brien 2003, p. 41)

But, necessarily, it was a fist the sergeant never felt.

Summing up so far: I have characterized O'Brien and Erik's use of friendship as one of the bidden, individual weapons of the weak, distinguished from open individual and from communal resistance, to the evil of comradeship as it appears amongst the other, closelyconnected evils of basic training, in its attack on individual agency, privacy, and ethical sensibility.

\section{Four}

By contrast, what follows from Orwell's account of basic and its results in Homage to Catalonia? For Orwell, comradeship was one of the goods of soldiering in the militia; it was closely connected with other goods, not least the capacity to resist fascism, actively pursued in basic; and it was part of a life which was - at least in potential-a kind of flourishing rather than a kind of corruption. As a way of getting clearer about those 
goods and that kind of flourishing, consider one of Rudyard Kipling's 'Epitaphs of the War, 1914-1918', 'Ex-Clerk':

Pity not! The Army gave

Freedom to a timid slave:

In which Freedom did he find

Strength of body, will, and mind:

By which strength he came to prove

Mirth, Companionship, and Love:

For which Love to Death he went:

In which Death he lies content.

(Kipling 1984)

The goods which Kipling here identifies, and which will help us to understand Orwell, are: freedom-from fear, class inferiority, and social constraint; strength-competence, power, the ability to act both individually and communally; courage — understood, as by Aristotle, as standing firm in the face of death; purpose-something for which the soldier can be content to die; and, of course, comradeship — mirth, companionship, and love.

But the obvious question to ask is, Why think that comradeship and the rest are goods? Why not think that Kipling, Orwell, and others who see the soldier's life as flourishing, are making a mistake — a mistake punctured by O’Brien, who reveals Kipling's 'goods' as the violent automatism of a human corrupted by basic? I want to suggest that comradeship, at least, should be recognized as a good because it is one of the central pleasures of being a soldier: it's one of the things which military memoirists in general, not just Orwell, typically look back on with delight. This claim may be misunderstood: I do not intend it as hedonistic. I am not claiming that the goodness of comradeship is the pleasure it gives, to be weighed against the various pains of soldiering (physical pain, humiliation, fear, boredom). I am claiming that pleasure is diagnostic, not constitutive, of the good, in much the same way that pain is diagnostic of damage, fear of danger, and sorrow of loss (this view is developed and defended in Clark forthcoming). The pleasure that military memoirists take in comradeship recollected in tranquility is a perception of its goodness, that is a perception of its constitutive role in a flourishing life.

The pleasure of comradeship is well analyzed by the American philosopher and World War II infantryman J. Glenn Gray, in his memoir and phenomenology of war The Warriors (Gray 1970). Gray suggests that there are three enduring appeals of battle: delight in seeing, delight in destruction, and delight in comradeship. He glosses the third 
as a 'confraternity of danger and exposure' (Gray 1970, p. 27). That's a particularly rich description, and hints at several important elements of the good of comradeship. First, there is exposure to shared danger, and the related pleasure of hard communal action under threat, when we act together for a definite and difficult aim, for keeps. It is tempting to take this as an example of Aristotle's understanding of pleasure as the completion of excellent activity (Aristotle 1999, X.4). It is natural to humans to take pleasure in carrying out their functions well, and acting as a soldier with other soldiers, like the communal hunt or team sports, can be the excellent expression of several central human capacities, including capacities for joint attention, reciprocal communication, and the coordination of multiple individual actions for a shared goal.

Second, there is the confraternity of having been exposed to extreme experience, and the related pleasure of consciously and reciprocally shared knowledge, as possessed by the audience to a secret performance ${ }^{1}$ : we both know, and know that the other knows, the fear and exhilaration of battle. We can each say to the other, 'I was there'.

Third, and most importantly for my purposes, Gray's description of the delight in comradeship hints at Orwell's air of equality: the confraternity of exposure is exposure not just to shared dangerous action or to shared experience; it is exposure to one another. The confraternity of soldiers is a social world in which each of us is seen and known by others who in return we also see and know. It is an egalitarian public sphere which is particularly visible in Orwell's egalitarian militia, but is also contained within the rigid hierarchy of ordinary armies — at least as a 'seed beneath the snow' (Ward 1973, p. 18). The loss of privacy in basic is a necessary preliminary to this confraternity: the features of basic which O'Brien so hated, and resisted, are not there just because drill sergeants are bastards. They are deliberate attempts to forge that kind of comradeship: reciprocal perception without secrets. Of course, the army tries to produce comradeship because it is a useful tool, that is an instrumental good if a good at all: comradeship, like bayonet drill, is a propaedeutic to hard communal action like storming enemy trenches. But the enduring delight that soldiers take in their comradeship suggests that it is also a constitutive good of a form of life which is, at least in potential, a kind of human flourishing. The pleasure that soldiers take in knowing and being known by their comrades diagnoses that form of egalitarian public life as good for them, and suggests that it is good for humans in general.

\footnotetext{
${ }^{1}$ Thanks to my colleague Cain Todd for this analogy.
} 
Summing up again: O’Brien's account of basic suggests that comradeship, as opposed to friendship, is one of the constitutive evils of a corrupt form of life, the life of the soldier. Orwell's account suggests the counter-claim that comradeship, understood as a confraternity of danger and exposure-exposure to shared danger and experience, but also exposure to one another-can be a constitutive good of a flourishing life as a soldier.

However: Orwell's point was a contrast between bourgeois societies and their armies on one hand, and egalitarian militias and the utopian society they hint at on the other. My discussion has elided that contrast, on purpose, because I think Orwell's contrast is wrong, or at least too stark. The egalitarian comradeship he found in the militias is not in complete opposition to what is there in ordinary armies; it was a discovery of one of the intrinsic goods of soldiering, made obvious by its separation from some contingent evils. In ordinary, hierarchical armies, at least during wartime, there is considerable equality at the platoon level: the group of a few dozen soldiers who live and risk their lives together, and who are willing to die for one another's sake (Junger 2010, book 3). For them, privacy would be too costly, since anything about a comradehow he ties his boots; whether he is drinking enough water-might make the difference between life and death for everyone. But they experience that mutual revelation as a pleasure — something good in the middle of terror-not as a further cost. This necessary platoon-level comradeship coexists with internal and external hierarchies, and is in tension at its borders, where officers mediate between the platoon and the chain of command. Which of comradeship and hierarchy is dominant varies with circumstance, but it is not clear that armies could do without the anti-hierarchical element of their organization. I therefore want to suggest, against Orwell and only slightly frivolously, that it is no accident that both old soldiers and old socialists call one another 'comrade'.

\section{Five}

I conclude with three tentative results of this exploration. First, we have engaged in some speculative moral psychology of soldiering, which is a neglected part of politics and of human life. We-that is people like me, citizens of Western democracies born well after World War II, who don't have family members in the forces—can tend to forget that we are unusual in the extent to which armies and soldiering are not part of our lives. But the soldier's life has been a central part of the human experience of the twentieth century, perhaps even more so than earlier centuries. My preliminary attempt at description is 
therefore worth having just as bringing a small amount of light to a currently-neglected corner of human ethical and political experience.

Second, the results of this exploration of individuality and comradeship lend support to value pluralism, in one but not another sense. The first kind of pluralism is anti-monism. Bentham (1970), for one example of a monist, believed that that there was only one intrinsically valuable thing, pleasure, understood as countable and fungible-like money. Anti-monists claim against this that several different things-achievement, pleasure, understanding, agency, and deep personal relations, for example — have distinct, non-fungible value (Griffin 1996; see also Frankena 1973, Nussbaum 2000). What I have done here, I believe, is reveal that soldiering and its alternatives involve different, nonfungible values: comradeship and individuality. These two intrinsic goods are difficult to combine, and a life involving each might properly be said to go well, despite lacking the other. A second kind of pluralism, however, is anti-rationalism: the view that no rational decisions can be made about clashes between distinct values. Michael Walzer (1983), for example, is an anti-rationalist about different forms of life, because he thinks there is nowhere for the putative rationalist to stand in judgement between, for example, the life of hedonistic self-fulfillment and the life of monastic self-abnegation. My exploration here does not entail that further, stronger claim. Becoming a soldier involves both gains and losses, as does not becoming one; to pursue one of these complex clusters of goods and bads is to prevent oneself from pursuing another. But what that might show is that the goal of the perfectionist, human flourishing, has a tree-like structure through time: a central trunk with branches, travelling down any of which excludes travelling down the others, and each part of which supports its own further extension. It does not need to be taken as showing that there are no reasons to take one branch rather than another. However, I have offered no guidance here about how to make such a choice: my aim was only to map a small part of the complex value landscape.

Third, I want to make a more ambitious claim: I want to say that the life of the soldier is not just part of ethical and political life; it is a microcosm of that life. Thinking about the goods and evils of the soldier's life, as experienced by O'Brien and by Orwell, helps uncover what we gain and what we lose in becoming part of a community, whether an army or a polis. As Orwell shows us, soldiering offers a window onto an attractive but also costly utopia, and I want to emphasise both the attractions and the costs. O'Brien is right: becoming a comrade demands serious losses, at least of privacy and perhaps, worse, of individuality and independence. But he is only half-right, because becoming a 
comrade also offers great gains: soldiers' pleasure in their comradeship diagnoses it as a significant human good.

That final claim may seem too ambitious a generalization from just two examples, for several reasons: twentieth-century total warfare was an unprecedented expansion and transformation of humans' social and destructive possibilities; soldiers, unlike citizens, must define themselves against an enemy; O'Brien was conscripted and Orwell volunteered (although as I noted in Section Two, O’Brien's participation was not in any simple sense non-voluntary); both were white, male, and educated. One response to these problems is to deny that generalization is necessary: what I have offered might only be 'another self heard from', in the same way that cultural anthropology gives us 'another country heard from' (Geertz 1993, p. 23). What it reveals is that humans can react-because two humans have reacted-in a particular way to particular circumstances. That possibility is not everything, but is something, discovered about the broad variety of human political life. I want to stake out a middle ground between this particularising response and full-on generalization from my two examples to the whole. What I suggest is that my examples should be taken as offers of human experience open to recognition and connection. Friendship need not always be a way of resisting oppression, but it is so in more than O’Brien's case-think of the intense friendships formed in hated schools, for example. Loss of privacy is a condition of the intimate goods of marriage as well as of comradeship. So, what I have done here is not only to map a small part of the territory of human value, but to offer triangulation-points for further mapping. As Geertz also suggests, one can 'draw large conclusions from small, but very densely textured facts' (Geertz 1993, p. 28).

A final summing-up: I have attempted to address the large question of the role of friendship in political life by investigating a particular complex case: the tensions between comradeship, as good and as evil in the lives of two soldiers, and friendship, as resistance to it. I claim that this exploration of a small but interesting part of human flourishing sheds light on a neglected area of human ethical and political experience; increases our understanding of value in human life; and is revealing about some of the costs and benefits of political life.

Acknowledgements: Many thanks to Derek Edyvane and Kerri Woods; to the other members of the panel on political friendship, Manchester workshops in political theory 
2010; to my colleagues and students at the University of Lancaster; and to Susan Mendus.

\section{References}

Alexander, Robert J. 1999. The anarchists in the spanish civil war. London: Janus Publishing Company.

Aristotle. 1999. Nicomachean ethics trans. Terence Irwin. $2^{\text {nd }}$ edn. Indianapolis: Hackett.

Bentham, Jeremy. 1970. An introduction to the principles of morals \& legislation, ed. J. H. Burns \& H. L. A. Hart. Oxford: Oxford University Press.

Bourke, Joanna. 1999. An intimate history of killing: face-to-face killing in twentieth-century warfare. London: Granta.

Clark, Samuel. 2010a. Love, poetry, \& the good life: Mill's Autobiography \& perfectionist ethics. Inquiry 53: 565-78.

Clark, Samuel. 2010b. Kicking against the pricks: anarchist perfectionism \& the conditions of independence. In Anarchism \& moral philosophy ed. Benjamin Franks \& Matthew Wilson, 33-44. London: Palgrave.

Clark, Samuel. Forthcoming. Pleasure as self-discovery. Ratio.

Craton, Michael. 1982. Testing the chains: resistance to slavery in the British West Indies. Ithaca: Cornell University Press.

cummings, e. e. 1969. 'i sing of olaf glad and big...' In Selected Poems 1923-1958, 25. London: Faber \& Faber.

Foot, Philippa. 2001. Natural goodness. Oxford: Oxford University Press.

Frankena, William K. 1973. Ethics. $2^{\text {nd }}$ edn. New Jersey: Prentice Hall.

Geertz, Clifford. 1993. Thick description: toward an interpretive theory of culture. In The interpretation of cultures: selected essays. London: Fontana.

Glover, Jonathan. 2001. Humanity: a moral history of the twentieth century. London: Pimlico.

Graves, Robert. 1960. Goodbye to all that. London: Penguin.

Gray, J. Glenn. 1970. The warriors: reflections on men in battle. With a new foreword. New York: Harper \& Row.

Griffin, James. 1996. Value judgement: improving our ethical beliefs. Oxford: Clarendon Press.

James, C. L. R. 1980. The black jacobins: Toussaint L'Ouverture \& the San Domingo revolution. London: Allison \& Busby.

Junger, Sebastian. 2010. War. London: Fourth Estate. 
Kipling, Rudyard. 1984. 'Ex-Clerk'. In The Oxford book of war poetry ed. Jon Stallworthy, 214. Oxford: Oxford University Press.

Nussbaum, Martha C. 2000. Women \& human development: the capabilities approach.

Cambridge: Cambridge University Press.

O’Brien, Tim. 1990. The things they carried. London: Flamingo.

O’Brien, Tim. 2003. If I die in a combat zone. London: Flamingo.

Orwell, George. 2001. Homage to Catalonia in Orwell in Spain, ed. Peter Davison, 28-215.

London: Penguin.

Pascal, Roy. 1960. Design \& truth in autobiography. London: Routledge \& Kegan Paul.

Preston, Paul. 1996. A concise history of the spanish civil war. Revised edn. London: Fontana Press.

Rawls, John. 1999. A theory of justice. Revised edn. Cambridge Massachusetts: Harvard University Press.

Scott, James C. 1985. Weapons of the weak: everyday forms of peasant resistance. New Haven: Yale University Press.

Walzer, Michael. 1983. Spheres of justice: a defence of pluralism \& equality. New York: Basic Books.

Ward, Colin. 1973. Anarchy in action. $2^{\text {nd }}$ edn. London: Freedom Press.

Yeats, W. B. 1989. 'An irish airman foresees his death'. In Yeats's Poems ed. A. Norman Jeffares, 237. London: Papermac. 